\title{
Creation of a raid complex as a promising direction for the development of the seaport of Petropavlovsk-Kamchatsky
}

\author{
Tatyana Miroshnikova ${ }^{1}$ and Natalia Taskaeva ${ }^{2 *}$ \\ ${ }^{1}$ Vladivostok State University of Economy and Service, Gogolya str., 41, Vladivostok, 690014, \\ Russia \\ ${ }^{2}$ Moscow State University of Civil Engineering, Yaroslavskoye Shosse, 26, Moscow, 129337, Russia
}

\begin{abstract}
Sea transport has a significant impact on the development of the country's economy. The development of the project to create a raid complex in the seaport of Petropavlovsk-Kamchatsky can give a new impetus to realizing the potential of the region. The problems of the development of sea transport are caused by the lag in the development of domestic seaports. Petropavlovsk-Kamchatsky can become a base port providing services of supply, bunkering, and vessel repair, technical and other inter-river service of ships. The additional cargo traffic of the point will affect the increase of cargo turnover in the Kamchatka Territory and the Northern Sea Route. The construction of the raid complex is a prospect for the development of maritime infrastructure. The authors presented a promising project with the resulting cash flows and calculation criteria for its effectiveness. In order to take into account the main risks associated with the construction of the raid complex, geological, engineering, construction, force majeure, sensitivity analysis to variable parameters has been carried out. The substantiation of the choice of the type of the raid quay facility is carried out. The proposed project has an economic and social effect, will ensure the development of the PetropavlovskKamchatsky sea terminal to the international level. The use of the transit potential of the territory is of strategic importance on a national scale.
\end{abstract}

\section{Introduction}

Sea transport has a special role in the transport system of the country, which is due primarily to the favorable physical and geographical conditions of Russia. This is the main foreign trade transport, because its share in the total volume of export-import cargo is about $60 \%$ [1]. Maritime transport and the maritime transport services market based on it are among the most important sectors of the modern world economy. The considered form of transport has a significant impact on the development of the country and the subjects of the Russian Federation, the achievement of geopolitical, economic and social goals. Russia's promising plans for the restoration and construction of port infrastructure directly affect the Kamchatka maritime transport system.

\footnotetext{
${ }^{*}$ Corresponding author: natalia.taskaeva@yandex.ru
} 
Implementation of effective management of the Kamchatka sea transport infrastructure in the conditions of development of international cooperation will ensure the development of the economy of the region and the realization of its potential. The leading place in the implementation of cargo flows in Kamchatka belongs to sea transport and seaports, which provide about $83 \%$ of all cargo turnover in the Kamchatka Territory [2]. In the region under consideration, the main transport hub is the Petropavlovsk-Kamchatsky seaport, the turnover of which in 2017 amounted to 880.6 thousand tons $(102.4 \%$ against the same indicator in 2016). The analysis shows that in recent years the port's cargo turnover has been kept at around 1 million tons. The boundaries of the seaport of PetropavlovskKamchatsky include terminals located in port stations on the coast of the Kamchatka Peninsula. The enterprises of sea transport are the most important link in the transport complex of the Kamchatka Territory. They reload about 300 thousand tons of fish products and more than 350 thousand tons of export-import cargo per year [2]. Sea transport carries out transportation of all kinds of food, material and technical supplies, fuel.

The development program of Open Joint Stock Company "Petropavlovsk-Kamchatsky sea commercial port" is based on: maintaining the volume of transshipment of goods at the level of 1 million tons per year; improving the quality of cargo processing; efficiency of operations; increasing additional port services; finding new cargo flows, making maximum use of existing production facilities; taking measures, aimed at reducing the cost of services provided [3]. The primary task aimed at ensuring the efficiency of the port and increasing competitiveness in the market of port services in the Kamchatka Territory is the development of production facilities, increasing the efficiency of existing production, upgrading and repair of port equipment. The state of the transport system at present cannot be considered optimal, and the level of its development is sufficient. In view of the remoteness of Petropavlovsk - Kamchatsky there is a problem of underdevelopment of infrastructure facilities and the costly nature of transportation. The level of cargo turnover is inferior to the indicators of previous years; the reorientation of a significant part of external cargo flows to foreign ports reduced the freight volumes [4].

\section{Materials and Methods}

According to statistical indicators, there is an unstable dynamics of employment of the quay port wall. In 2017, the number of vessels handled is reduced compared to 2016 and, accordingly, the berth's employment is only $81 \%$ compared to the previous year. In 2017 , there was a significant decrease in the number of vessels processed (142 units) versus 2015 by $39.6 \%$. In 2017 , the port handled 142 vessels. The average load of the vessel was 6.201 tons. In 2017, two lines operated in the port of Petropavlovsk-Kamchatsky: 43 linear ships were processed at FESCO (Vladivostok-Petropavlovsk-Kamchatsky-Vladivostok), 286.7 thousand tons of cargo were processed; KASCO (Vladivostok-Petropavlovsk-KamchatskyVladivostok) handled 56 linear vessels, processed 364.200 tons of cargo. The figure 1 shows the dynamics of the number of vessels processed for the period 2011-2017 [5]. 


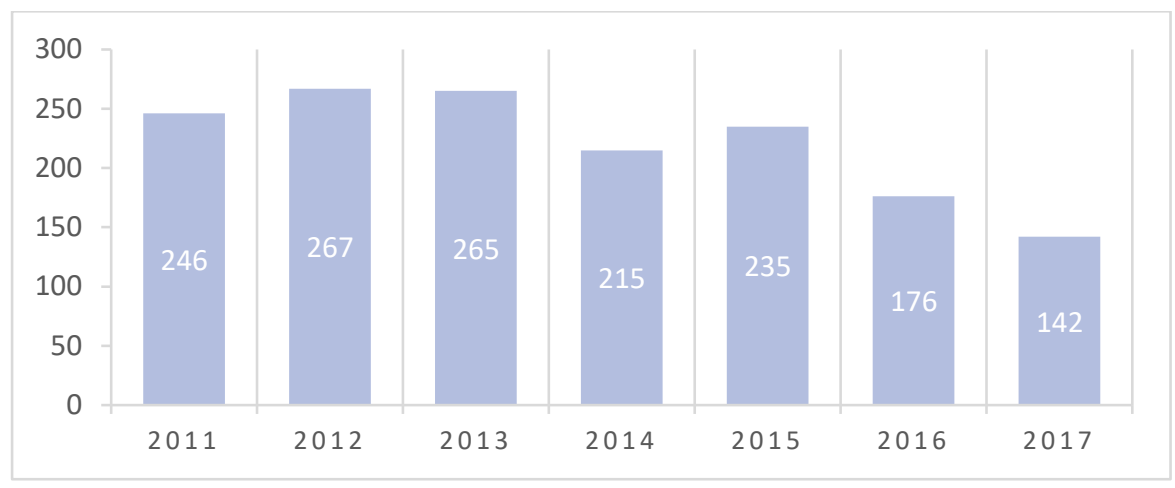

Fig. 1. Number of vessels processed in 2011-2017

The main problems in the development of maritime transport are due to the insufficient scale of the use of modern transport technologies, primarily container, ferry, lighter, and behind the development of domestic seaports and the organization of large transport and logistics nodes on their basis.

According to the press service of the Ministry of Development of the Far East, by 2020 the increase in the production capacity of Russian ports in the Far Eastern Federal District will be 12 million tons per year. To this end, 57 billion rubles will be allocated for the development of maritime transport infrastructure by the specified time, including 8.8 billion rubles from the federal treasury. Such funds are laid in the "Far East section" of the state program "Development of the transport system of Russia (2010-2020)" [7].

Kamchatka region, due to its geographical position, has a high transport potential. The Kamchatka Krai, through the development of port facilities and the creation of a transportbunkering center, can act as a strategically important subject of the Russian Federation, directly determining the state's perspective capabilities in creating an effective international northern transport system. The growth of the economy of the Kamchatka Krai can be achieved in those areas where it has real competitive advantages in regional and world markets. In this regard, the creation of a port and logistics center will ensure the development of the Petropavlovsk-Kamchatsky sea terminal to the international level [8].

Large depths at the berths allow large-tonnage vessels to be accepted. Nomenclature of goods: coal, oil products, construction materials, machinery, equipment, supplies, food, objects of mass demand. Loading and unloading works are mechanized. There is a shipyard. The port of Petropavlovsk-Kamchatsky is located in close proximity to the international shipping lines, which pass at a distance of 150-200 nautical miles from the eastern coast of Kamchatka [9].

\section{Results}

Petropavlovsk-Kamchatsky port can become a key point for the deposit and transfer of cargo from non-ice class vessels to icebreaker class vessels. Here it is possible to organize a transshipment for ships transporting goods from Europe to different destinations in the Pacific and from Asia-Pacific countries - to Northern Europe, North America and Canada [10]. Petropavlovsk-Kamchatsky can become a base port on the eastern shoulder of the northern sea route, providing services for supply, bunkering, and vessel repair, technical and other inter-river service of ships. Further development of the port is possible with the construction of a raid dock several miles from the coast [11].

Thus, the purpose of this study is to develop a project to create a raid complex in the seaport of Petropavlovsk-Kamchatsky, which contributes to the growth of cargo turnover. 
One of them is a raid complex for transshipment of oil and oil products. He makes refueling, refueling ships directly on the roadstead without mooring at the berth. This allows servicing ships with a large draft even in ports where there are no suitable deepwater berthing facilities. In this case, there is no need to deepen the bottom, investing large amounts of money in modernization, or improving the infrastructure of the port. This greatly simplifies the process of calling a vessel into the port, accelerates it, and reduces the costs associated with creating a port-point.

The subject of the study is to assess the growth of cargo traffic by creating a raid berth in the Kamchatka Territory. An indicative example is the port of world significance Singapore. Almost $50 \%$ of sea ship calls provide bunkering, both in the roadstead and in its internal part. Accordingly, the construction of the complex in the water area of the port contributes to an increase in the total cargo turnover. Vessels entering the port zone of Petropavlovsk Kamchatsky can be serviced both in the roadstead and near the shore. Dry cargo vessels and other carriers in the future will carry out cargo transshipment, use ship repair services directly near the shore, and bunker in the roadstead. At present, the number of ship calls is an average of 142, with the construction of a raid berth it can almost double. For comparison, in the port of Singapore, the daily call of vessels is 230 units of sea transport. The additional cargo traffic of the point will affect the increase of cargo turnover not only in the Kamchatka Territory, but also in the Northern Sea Route. Therefore, the construction of the raid complex is an opportunity to increase the port's throughput, the potential for further development of the maritime infrastructure, the prospect of development, and possibly the construction of a world-class hub port [12].

Raid oil-loading berths are located at a considerable distance from the coast to ensure sufficient depths and avoid expensive dredging. Loading of oil to the tanker is carried out on the shore by the oil storage, then oil products are delivered to the raid complex and bunkering of fuel is carried out on the raid berth. That is, the bunkering vessel delivers the processed oil to the ship anchored at the raid dock.

In the practice of port construction for reception of tankers raid mooring structures of the following types are erected: single-point stationary - in the form of a mooring steel tower and floating multipoint with mooring of the vessel for several anchored mooring barrels.

A single-point berth may moor at a high wave height; the process of refueling ships can take place under adverse climatic conditions. The degree of ease of berthing 1-suggests that the process is less time-consuming, ships are moored to the raid faster, with the least amount of time. At the same time, less auxiliary equipment is required; accordingly, the costs of servicing the mooring and bunkering process are reduced. A single-point berth can accommodate a greater number of vessels than a multipoint one. This is because the mooring speed is higher, the time of the vessel's stay at the berth is less, and accordingly the patency of this complex is greater.

\section{Discussion}

The theoretical operational time of the multipoint berth is 306 days, 7344 hours per year. The time of the vessel's stay at the berth is 18.5 hours, the time between moorings is 20.5 hours, respectively, and the time interval spent by one vessel is 39 hours. Therefore, the number of vessels that can service the port is 179. In the case of a single-point berth, 69 increase the number of calls.

Each vessel is on average 10.000 tons loaded, which means that vessels can consume up to 1.79 million tons per year at a multipoint berth, and in the single-point area by 0.69 million more. The cost of 1 ton of fuel in Russian ports on average, $\$ 500$, therefore, the greater the permeability of the bunkering complex, the greater the income of the port. The 
useful life of the multipoint berth is 2 years longer than the one-point complex, is 12 years. Total operating costs of a single-point berth are more by $\$ 0.786$ million.

Thus, the single-point berth has a number of operational advantages: the mooring process is easier, under unfavorable climatic conditions, it is possible to use this berth (the time of downtimes in the storm decreases), the patency of the complex is higher, which implies consideration of this type of berth for construction in the port of PetropavlovskKamchatsky.

The main purpose of the proposed construction project is to increase the flow of goods in the water area of the port of the Kamchatka Territory. The number of traffic along the northern sea route is increasing, there are no pirate attacks taking place in other directions. Companies bear high costs to ensure safe passage through the sea.

In the Kamchatka Territory there are over 300 enterprises engaged in fishery activities. A large number of ships year-round makes numerous calls to the port for refueling and goes to sea. If fishers can refuel in their own port, the ship's operating time will be shortened, the cost of refueling in other ports will decrease, and the process will be facilitated. Therefore, the development of the berth is very important not only in the scale of the country, but also for the Kamchatka Territory, in particular for the provision and development of fishing. Cost of construction of a single-point roadside quay (Table 1).

Table 1. Cost of construction of a single-point roadside quay

\begin{tabular}{|l|c|}
\hline Cost Objects & Amount, mln \$ \\
\hline Project Planning and Management & 17.6 \\
\hline Point mooring & 38.5 \\
\hline Internal pipelines and auxiliary facilities & 6.4 \\
\hline Treatment facilities & 5.1 \\
\hline Administrative-household block, warehouses & 3 \\
\hline Unforeseen expenses (20\% of n 2.10\% of items 3-6) & 9.15 \\
\hline Total & 79.75 \\
\hline
\end{tabular}

The total cost of the construction of the raid complex is 79.75 million dollars. We calculate the income of the sea trading port from refueling ships (Table 2).

Table 2. Calculation of the merchant port revenue from refueling

\begin{tabular}{|l|l|}
\hline Sales volume, billion \$ & 1190 \\
\hline Cost of delivery, billion \$ & 1071 \\
\hline Operating costs & 4.343 \\
\hline Profit before tax, million \$ & 114.7 \\
\hline Profit tax, million \$ & 22.9 \\
\hline Net income from the operation, million \$ & 91.7 \\
\hline
\end{tabular}

Net income from transportation of oil from the point of departure to the destination point for the year is $\$ 91.7$ million.

In addition to the bunkering of vessels, the income of the port is income from entering the port, which averages 250.000 rubles per vessel, or 59.5 million rubles for 238 ships $(\$$ 1.75 million). The operating costs for servicing tankers of the port of Kamchatka, which provide entry, mooring, towing to the ships arrived are $\$ 0.1$ million. Then the profit from calling at the port after paying income tax is $\$ 1.32$ million. Total income and operating expenses from calls to port and ship bunkering (Table 3 ). 
Table 3 Total income and operating expenses from calls to port and ship bunkering

\begin{tabular}{|l|l|ll|}
\hline Income & Costs & Profit & \\
\hline $\begin{array}{l}\text { Bunkering (net of } \\
\text { transportation costs) - } 119 \\
\text { million. }\end{array}$ & $\begin{array}{l}\text { Amortization (pier) - \$ 3.85 } \\
\text { million }\end{array}$ & $\begin{array}{l}\text { Bunkering ships-91.7 } \\
\text { million \$ }\end{array}$ \\
\hline $\begin{array}{l}\text { Calls to the port - } 1.75 \\
\text { million. }\end{array}$ & $\begin{array}{l}\text { Content (berth) -0.390 } \\
\text { million \$ }\end{array}$ & $\begin{array}{l}\text { Port calls \$ } \\
\text { million }\end{array}$ \\
\hline & $\begin{array}{l}\text { The cost of auxiliary vessel } \\
\text { services is \$ 0.063 million. }\end{array}$ & - \\
\hline & $\begin{array}{l}\text { Personnel pay-\$ 0.140 } \\
\text { million }\end{array}$ & - & \\
\hline Income & Total-4.443 million \$ & Total-93.02 million \\
\hline
\end{tabular}

The raid complex is built at the expense of the federal budget and private company funds. The interaction of the state and business takes place to solve socially significant tasks on mutually beneficial terms. The form of cooperation is public private partnership, where $50 \%$ of investment funds are paid by the state, another company that uses credit funds to implement the project at $18 \%$ per annum for 3 years. The resulting cash flows give net present value, accumulated total, $\$ 117$ million. The project is highly profitable. The profitability index is equal to 2.46 . For all indicators, this project can be considered effective, it should be recommended for implementation.

The main risks associated with the construction of the raid complex will be geological, engineering, construction, force majeure. To varying parameters in the analysis of sensitivity should include: a decrease in demand for services and an increase in annual costs. The change in two factors significantly affects the amount of discounted cash flow. The state incurs losses in the event of a change in demand and a change in the price of fuel. In this case, under the expected conditions, the goal for which the project is carried out is achieved, this is the development of the region and the sea route.

\section{Conclusion}

The construction of the raid complex affects the change in the cargo flow of the port of Petropavlovsk-Kamchatsky. Increased by 238 vessels turnover, gives an increase in calls to the berth by $90 \%$ [12]. At the first stage of the development of a sea port-point, the quay is constructed on a roadstead, which is run by fishing ships, incoming ships from Asia and Europe and passing by. Due to the increase in ship calls to the raid, the general cargo traffic of the port is growing (Table 4).

Table 4. Influence of the raid complex construction on the turnover of goods

\begin{tabular}{|l|l|l|l|}
\hline Indicators & $\begin{array}{l}\text { before the } \\
\text { project }\end{array}$ & $\begin{array}{l}\text { After } \\
\text { implementation } \\
\text { the project }\end{array}$ & of \\
\hline $\begin{array}{l}\text { Number of vessels processed, } \\
\text { units port }\end{array}$ & 290 & 341 & 108.5 \\
\hline $\begin{array}{l}\text { Number of vessels processed, } \\
\text { units port }\end{array}$ & 238 & 238 & - \\
\hline $\begin{array}{l}\text { Number of vessels processed, } \\
\text { units }\end{array}$ & 528 & 579 & 104.5 \\
\hline The result of vessel handling: & 282 & 297 & 108.1 \\
\hline in time, units. & 246 & 282 & \\
\hline
\end{tabular}


The construction of the raid berth, affects the final indicator of cargo traffic, the increase in the number of vessels processed and the positive dynamics in terms of cargo turnover directly at the port. Taking into account the growth trend of ship calls (by 8.5\%), we can assume that in the following years the dynamics of growth will continue. The main increase in ship calls to the harbor area will be provided by the construction of a berth at sea.

The construction of the raid complex will increase the flow of the port of Kamchatka, make it more attractive for investors and foreign companies engaged in sea transportation. At the moment, the Petropavlovsk-Kamchatsky commercial port does not have its own oil storage, tank depots and oil pipelines, therefore refueling of ships will be carried out thanks to transportation of fuel from Sakhalin Island. The price of sales of processed oil is taken as average by Russian standards. Foreign fuel costs an order of magnitude more, on average by $20 \%$. This is another fact that can attract foreign cargo shippers. The creation of the port-logistics center will ensure the development of the Petropavlovsk-Kamchatsky sea terminal to the international level. The mechanism, the implementation of elements of which will ensure the competitive position of maritime transport in the region also includes the delineation of bunkering functions, cargo transportation and passenger tourism between the port territories; use of the transit potential of the territory of the Kamchatka Peninsula due to the advantage of the geographic location of the Kamchatka Territory.

\section{References}

1. On the approval of the Strategy for the socio-economic development of the Far East and the Baikal region for the period until 2025: the order of the Government of the Russian Federation 28 December, 2094-p (2009)

2. Transport strategy of the Russian Federation for the period until 2030: the order of the Government of the Russian Federation 22 November, 1734-p (2008)

3. Annual report of Open Joint Stock Company "Petropavlovsk-Kamchatsky sea commercial port" for 2017

4. On the approval of the state program of the Russian Federation "Development of the transport system": Resolution of the Government of the Russian Federation No. dated 15April, 319 (2014)

5. URL: http://kamstat.gks.ru/wps/wcm/connect/rosstat_ts/kamstat/resources/ 55afdd80472a30088635be87789c42f5 / Report + 1.3.1.rar

6. Transportation of the Kamchatka Krai a statistical compilation. PetropavlovskKamchatsky: Kamchatstat (2016)

7. URL: http://www.vestipk.ru/?id=12037

8. Strategy for the development of the Arctic zone of the Russian Federation and ensuring national security for the period until 2020.

9. URL: http://aftershock.su/?q=node/36048

10. URL: http://www.transportrussia.ru/transportnaya-politika/svezhee-dyhaniearktiki.html

11. Strategy of social and economic development of the Kamchatka Territory until 2025: Resolution of the Government of the Russian Federation 27July, (2010). JSC "Renewable Energy Engineering Center"

12. Interactive showcase of the Federal State Statistics Service [http://cbsd.gks.ru/] 